\title{
How Does the Entrepreneurs' Financial, Human, Social and Psychological Capitals Impact Entrepreneur'S Success?
}

\author{
Ashraf Elsafty ${ }^{1}$, Dalia Abadir ${ }^{1} \&$ Ashraf Shaarawy ${ }^{2}$ \\ ${ }^{1}$ Adjunct Assistant Professor, Maastricht School of Management, Cairo Outreach, Egypt. ORCID ID: \\ https://orcid.org/0000-0002-9377-7286. E-mail: ashraf@ashrafelsafty.com \\ ${ }^{1}$ Executive Coach and Trainer, Cairo, Egypt. E-mail: daliaabadir@gmail.com \\ ${ }^{2}$ Senior Researcher, Dr. Ashraf Elsafty Consulting, Giza, Egypt. E-mail: a.sharawy@ashrafelsafty.com \\ Correspondence: Ashraf Elsafty, Adjunct Assistant Professor, Maastricht School of Management, Cairo Outreach, Egypt. \\ ORCID ID: https://orcid.org/0000-0002-9377-7286
}

Received: August 24, 2020

doi:10.11114/bms.v6i3.4980
Accepted: September 15, 2020

Online Published: Septemebr 24, 2020

URL: https://doi.org/10.11114/bms.v6i3.4980

\begin{abstract}
The literature has widely covered the factors that determine the success of entrepreneurial ventures from financial and organizational perspectives. This study intends to tackle how the Financial Capital, the Human Capital, the Social Capital, and the Psychological Capital of the Entrepreneur affect Entrepreneurial Success. Despite that the Financial, Human, and Social Capitals are extensively examined in the literature as they relate to entrepreneurial success, this paper will add the psychological capital of the entrepreneur and examine its effect on entrepreneurial success in Egypt.

This study aimed to investigate the effect of Financial Capital, Human Capital, Social Capital, and Psychological Capital on Entrepreneurial Success using a cross-sectional survey. Respondents were the owners and founders of small and medium enterprises (SMEs) in Cairo, Egypt. The results revealed that Social Capital and Psychological capital had a statistical significance as well as a positive strong relationship with Entrepreneurial success, while the Financial Capital and the Human Capital had statistical insignificance as well as a positive weak to a very weak relationship with Entrepreneurial success respectively.

The study findings suggested that entrepreneurial success is strongly connected to the intangible resources of the entrepreneur, which are Social Capital and Psychological Capital, and that the Psychological Capital had the highest impact on Entrepreneurial success. However, the impact of the Financial Capital and Human Capital on Entrepreneurial Success was statistically insignificant.
\end{abstract}

Keywords: intangible resources, financial capital, human capital, social capital, psychological capital, competitive advantage, entrepreneurial success

\section{Introduction}

Entrepreneurship has increasingly gained much attention from business as well as economic researchers. Entrepreneurship improves the economy by creating jobs, promotes social change by enhancing the standard of living, and provides the society with various goods and services that improve social welfare. However, the journey of entrepreneurs is very challenging where many nascent and new businesses may fail to grow up as a business. Therefore, entrepreneurial success along with its factors can be considered important for the entrepreneurship business to continue, flourish, and grow. Among new business and startups only $10 \%$ of the small businesses survive three years of operation (Vesper, 1990), in which a company can be called successful if it is established for a minimum of three years (Watson, Hogarth-Scott, \& Wilson, 1998; Taormina \& Lao, 2007; Vesper, 1990; Makhbul \& Hasun, 2011).

In order to ensure a comprehensive contextual analysis, researchers analyzed the research in hand with the perspective of the proposed contextual framework of Elsafty (2018) that analyzes social study cases, as an anatomy model to closely study organizations and different contextual cases before attempting to solve any noticeable problems. As researchers in general face difficulties addressing their newly selected problem, especially post-graduate candidates for the first time, Elsafty (2018) introduces a framework of nine elements to enable researches to formulate clearly defined and focused problem definition, and a comprehensive framework to analyze the case researched with a comprehensive 
contextual analysis. Especially within social studies, the framework consolidates all relevant elements in one place acting as 'Anatomy' of the context studied.

On the way to contextual analysis of the research, Elsafty $(2018,2019,2020)$ provided a holistic framework to analyze the case using nine elements covering the whole ecosystem of educational organization(s) and all related stakeholders, including suppliers, distributors, customers, competitors, government agencies, and so on - involved in the delivery of educational outcomes, and related service through both competition and cooperation. Elsafty (2018) framework illustrates the interrelations among all elements affecting the research problem, where each element in the framework affects and is affected by the others, creating a constantly evolving relationships in which each element must be flexible and adaptable to survive, as in a biological ecosystem.

The nine elements framework has been used in several research papers (Elsafty, Elsayed, \& Shaaban, 2020; Elsafty \& AlNawaly, 2020; Elsafty \& Ragheb, 2020) as well as within professional consultancy, the framework helped diverse types of organizations (industrial, food, service, educational, trade, ... etc.) analyze their problems and properly address it in a comprehensive way to reach proper outcomes for decision making. While in education, the framework supported and used by postgraduates (overall number exceeds 3000+ students, since 2011 till 2020) to develop their research projects, thesis and dissertations by formulating a rigorous problem definition and contextual analysis for their researches.

Using the nine elements framework, the authors believe that this new perspective helped discover the underlying factors that are causing the problems faced by the research in hand, and resulted in the coming contextual analysis defining the research scope and focus, which in the case of this paper is on entrepreneurial success and how does the entrepreneurs' financial, human, social and psychological capitals impact it.

By looking at the Egyptian entrepreneurship ecosystem in the past years, it shows that it has grown on many levels: from initiation venture capital funds, to the launching of Micro, Small and Medium Enterprises Development Agency (MSMEDA) in April 2017, as a successor entity to the Social Fund for Development (SFD) in order to develop the MSMEs sector, to pumping investments in technology startups, to starting many entrepreneurship support programs as well as startup incubators and accelerators, to issuing new laws and decrees for investments, bankruptcy, and industrial licensing (Ismail, Tolba, Barakat, \& Meshreki, 2018). All these reforms, activities, and initiatives have positively affected the entrepreneurship ecosystem in Egypt, yet it still ranks low in most of the measures compared to GEM global averages (Ismail et al., 2018).

According to (Ismail et al., 2018) Entrepreneurship is perceived as a good career choice by $75.9 \%$ of Egyptians, this reflects the growth of the entrepreneurial culture, especially within youth. Moreover, the GEM report highlights that there is a high-status association with successful entrepreneurship by $82.0 \%$ of Egyptians; this puts Egypt as the 3rd of 52 countries in this area, which reflects the growing role model stature of the "successful entrepreneur", especially among youth (Ismail et al., 2018). The entrepreneurship process involves different phases or types of activities: it starts with the intention to start a new business, then opening a nascent business (up to 3 months old), to managing the new business ( 3 months to 3.5 years old), to becoming an owner of established business (older than 3.5 years), and finally the probability of discontinuation of business (Ismail et al., 2018).

According to the GEM report, the Total early-stage entrepreneurial activity (TEA) rate in Egypt of $13.3 \%$ which is to some extent higher than the global average of $12.3 \%$ reveals that early-stage entrepreneurs that are currently either in the phase of starting a new business or have started a business that is younger than 3.5 years are quite high in number if we compare them to the established business ownership rate of $5.7 \%$ versus the global average of $8.5 \%$ (Ismail et al., 2018). Moreover, Egypt's business discontinuation rate is $10.2 \%$ versus the global average of $3.2 \%$, this puts Egypt as rank 1 among 54 other countries, which is an alarming rate that a large population of business owners and entrepreneurs have discontinued their business (Ismail et al., 2018). Fewer businesses survived the early-stage phase and moved to the established business phase, this can be due to many reasons, but this study will focus on the intangible resources of the entrepreneurs and examine its effect on the entrepreneurial success in Egypt. According to the GEM report 2017, the new business rate in Egypt is higher than the global average where it is 7\% compared to 5.5\% worldwide. Similarly, the TEA rate in Egypt is $13.3 \%$ which is higher than the worldwide rate of $12.3 \%$. However, the Established business ownership rate in Egypt with $5.7 \%$ is considerably lower than the worldwide rate of $8 \%$. Also, the Business discontinuation rate is $10.2 \%$ in Egypt compared to $3.2 \%$ worldwide (Ismail et al., 2018).

Although there is much literature that studied entrepreneurial success, little is known about the factors that affect entrepreneurial success in Egypt. The purpose of this study is to investigate the impact of the financial, human, social, and psychological capitals of the entrepreneur on the entrepreneurial success in Egypt using correlation research design for Egyptian entrepreneurs with at least three years of business operations of either micro, small or medium enterprises. The significance of this study is to provide direction to entrepreneurs on the skills and capabilities they need to develop 
as well as training providers on the education needed to improve entrepreneur's likeliness to succeed. Moreover, giving insights to investors, incubators, and accelerators on the profile of the entrepreneur that has the potential to thrive. This study contributes to entrepreneurship literature by studying the impact of the factors that affect entrepreneurial success in Egypt.

\section{Literature Review}

\subsection{Entrepreneurial Success}

Although entrepreneurial success is often discussed in the literature, there is no consistent and accepted definition identified (Fisher, Maritz, \& Lobo, 2014). The term entrepreneurial success is used in literature in two different but related contexts. On one hand, it is used in the studies about the success of the entrepreneurial business venture and its activity. In these studies, researchers describe the success of entrepreneurial business in terms of the economical performance of the firm such as sales revenue, productivity, growth rate, profit, increase in the number of employees, and return on assets. On the other hand, the entrepreneurial success term is used in the studies of the success of the entrepreneurs themselves. Researchers interested in those studies noticed that using the same success description and criteria of success of the business is not sufficient per se. They contended that describing entrepreneurial success in financial and economic terms represents the objective dimension of the success. However, entrepreneurial success is multi-dimensional and it should include other subjective factors that represent the viewpoint of entrepreneurs about their success. Studies about this subjective dimension include other factors to describe success such as personal fulfillment, independence, work-life balance, social and personal relationships, and personal satisfaction (Fisher, Maritz, \& Lobo, 2014; Orser and Dyke, 2009; Wach, Stephan, \& Gorgievski, 2015; Wach, Stephan, Gorgievski, \& Wegge, 2018).

Orser \& Dyke (2009) studied entrepreneurial success as viewed by Canadian entrepreneurs who made their business grow. They expressed their success in terms of four areas that represent both the objective and subjective dimensions. These four areas are market acceptance, economic and financial aspects, work-life balance, and autonomy. Similarly, Gorgievski, Ascalon, \& Stephan (2011) provided multiple criteria to describe entrepreneurial success. These multiple criteria define success in terms of business venture performance as well as an entrepreneur's goals. Gorgievski et al. (2011) added that the entrepreneur's personal values shape their view about entrepreneurial success. Moreover, small business owners and entrepreneurs consider the personal criteria preceding the business success criteria.

Wach et al. (2018) suggested that entrepreneurs view their success through goal achievement. It is worth noting that goal achievement is subjective and individual and it relates to achieving the targeted outcomes. Consequently, Wach et al. (2015) defined subjective entrepreneurial success as "the individual understanding and assessment of the achievement of criteria that are personally important to the entrepreneur".

In this study, the researchers adopt the dimensions of the view of entrepreneurial success as a multi-dimensional concept, the objective, and subjective ones.

\subsection{Entrepreneurial Success Models}

Lussier (1995) reviewed the literature and identified fifteen variables that can predict the success or failures of businesses (Lussier, 1995; Marom \& Lussier, 2014; Baidoun, Lussier, Burbar, \& Awashra, 2018). Little consistency was found in the literature to support which variables predict success vs. failure. The three most frequently stated variables out of the fifteen variables are management experience, working capital, and planning.

As emphasized by (Hmieleski, Carr, \& Baron, 2015), the most important factors for the successful development and growth of firms are human capital (the knowledge, skills, and abilities that founders carry that help them in developing and growing their firms), social capital (the benefits entrepreneurs obtain from their social networks), and psychological capital. Envick (2005) proposed a more comprehensive model about the factors that impact the entrepreneurial success. He adapted the expanding capital model proposed by Luthans, Luthans, \& Luthans, (2004) which provides the relations between human capital, social capital, financial capital, and psychological capital and the sustained competitive advantage for the firm.

Envick (2005) model as Figure 1 shows that for an entrepreneur to start his venture, the following are needed; the financial capital, the entrepreneur(s)' human capital, the social capital that allows the venture to benefit from the entrepreneurs' network to gain more strength and the psychological capital that is in every sense as important to the other forms of entrepreneurs' capital as it effectively mobilizes the financial, human, and social capital to achieve success (Luthans et al., 2004; Envick, 2005). 


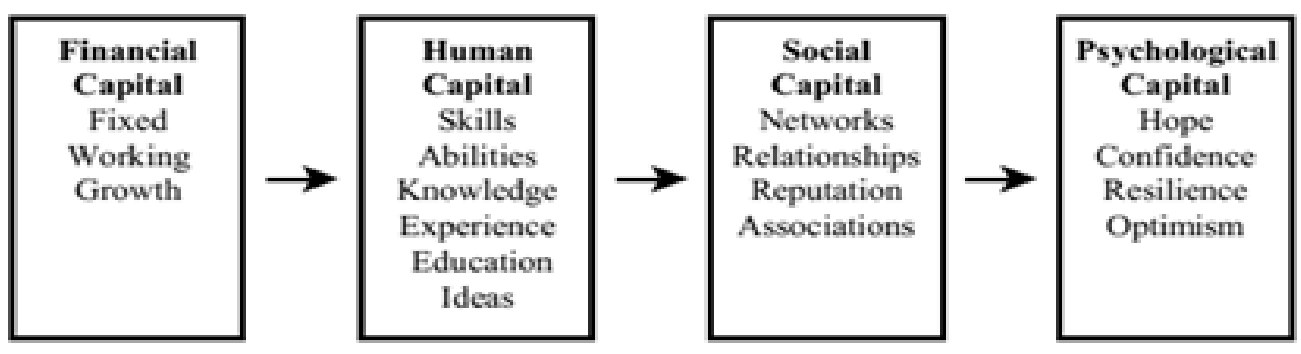

Figure 1. Expanding capital for entrepreneurial success

The researchers used Expanding Capital for Entrepreneurial Success model as a benchmark to review other models of entrepreneurial success to identify the most general variables of entrepreneurial success, as shown in Table 1 . The various and different variables that are widely spread between the models can be classified according to the different forms of capital, the financial, the human, the social the psychological capital, and others. 
Table 1. The classification of various variables of entrepreneurial success models into financial, human, social, and psychological capital

\begin{tabular}{|c|c|c|c|c|c|c|c|}
\hline SN & Model & Author(s) & $\begin{array}{l}\text { Financial } \\
\text { Capital }\end{array}$ & $\begin{array}{l}\text { Human } \\
\text { Capital }\end{array}$ & Social Capital & $\begin{array}{l}\text { Psychological } \\
\text { Capital }\end{array}$ & Others \\
\hline 1 & $\begin{array}{l}\text { Expanding } \\
\text { Capital for } \\
\text { competitive } \\
\text { advantage }\end{array}$ & $\begin{array}{l}\text { Luthans et al. } \\
\text { (2004) }\end{array}$ & Finances & $\begin{array}{l}\text { Experience, } \\
\text { Education, } \\
\text { Skills, } \\
\text { Knowledge, } \\
\text { Ideas }\end{array}$ & $\begin{array}{l}\text { Relationships, } \\
\text { Network of } \\
\text { Contacts, } \\
\text { Friends }\end{array}$ & $\begin{array}{l}\text { Confidence, } \\
\text { Hope, } \\
\text { Optimism, } \\
\text { Resilience }\end{array}$ & $\begin{array}{l}\text { Tangible assets } \\
\text { (plant, equipment, } \\
\text { patents, } \\
\text { data) }\end{array}$ \\
\hline 2 & $\begin{array}{l}\text { Expanding } \\
\text { Capital Model of } \\
\text { Entrepreneurial } \\
\text { Success }\end{array}$ & $\begin{array}{l}\text { Envick } \\
(2005)\end{array}$ & $\begin{array}{l}\text { Fixed } \\
\text { Working } \\
\text { Growth }\end{array}$ & $\begin{array}{l}\text { Skills, } \\
\text { Abilities, } \\
\text { Knowledge, } \\
\text { Experience } \\
\text { Education, } \\
\text { Ideas }\end{array}$ & $\begin{array}{l}\text { Networks, } \\
\text { Relationships, } \\
\text { Reputation, } \\
\text { Associations }\end{array}$ & $\begin{array}{l}\text { Hope, } \\
\text { Confidence, } \\
\text { Resilience, } \\
\text { Optimism }\end{array}$ & \\
\hline 3 & $\begin{array}{l}\text { Human capital \& } \\
\text { entrepreneurial } \\
\text { success }\end{array}$ & $\begin{array}{l}\text { Unger et al. } \\
(2011)\end{array}$ & & $\begin{array}{l}\text { Human } \\
\text { capital }\end{array}$ & & & $\begin{array}{l}\text { Context of the } \\
\text { firm }\end{array}$ \\
\hline 4 & $\begin{array}{l}\text { The Conceptual } \\
\text { Model of } \\
\text { Entrepreneurial } \\
\text { Success (Success } \\
\text { of the enterprise } \\
\text { phase of the } \\
\text { model) }\end{array}$ & $\begin{array}{l}\text { Kumar } \\
(2007)\end{array}$ & & & & Self-Efficacy & $\begin{array}{l}\text { Relative } \\
\text { Cognitive } \\
\text { Complexity, } \\
\text { Environment }\end{array}$ \\
\hline 5 & $\begin{array}{l}\text { The } \\
\text { Entrepreneurial } \\
\text { Capital Model }\end{array}$ & $\begin{array}{l}\text { Erikson } \\
\text { (2002) }\end{array}$ & & & & & $\begin{array}{l}\text { Perceived } \\
\text { entrepreneurial } \\
\text { competence, } \\
\text { Commitment, } \\
\text { goals }\end{array}$ \\
\hline 6 & $\begin{array}{l}\text { General Model } \\
\text { of } \\
\text { Entrepreneurial } \\
\text { Success }\end{array}$ & $\begin{array}{l}\text { Rauch and } \\
\text { Frese (2000) }\end{array}$ & & $\begin{array}{l}\text { Human } \\
\text { Capital }\end{array}$ & & & $\begin{array}{l}\text { Personality, } \\
\text { Strategies, Goals, } \\
\text { Environment }\end{array}$ \\
\hline 7 & $\begin{array}{l}\text { Human and } \\
\text { Social } \\
\text { Capital } \\
\text { Investments }\end{array}$ & $\begin{array}{l}\text { Bosma et al. } \\
(2000)\end{array}$ & & $\begin{array}{l}\text { Human } \\
\text { Capital }\end{array}$ & Social Capital & & \\
\hline 8 & $\begin{array}{l}\text { Psychological } \\
\text { typology \& \& } \\
\text { entrepreneurial } \\
\text { success }\end{array}$ & $\begin{array}{l}\text { Miner, J. B. } \\
\text { (1997) }\end{array}$ & & & & & Personality types \\
\hline 9 & $\begin{array}{l}\text { The Lussier } \\
\text { success } \\
\text { prediction model }\end{array}$ & $\begin{array}{l}\text { Lussier } \\
\text { (1995) }\end{array}$ & Capital & $\begin{array}{l}\text { Industry } \\
\text { experience, } \\
\text { Management } \\
\text { experience, } \\
\text { Education, }\end{array}$ & $\begin{array}{l}\text { Professional } \\
\text { advisors }\end{array}$ & & $\begin{array}{l}\text { Record keeping } \\
\text { and financial } \\
\text { control, Planning, } \\
\text { Staffing, } \\
\text { Product/services } \\
\& \quad \text { economic } \\
\text { timing, age of } \\
\text { owner, partners, } \\
\text { parents, minority, } \\
\text { Marketing skills }\end{array}$ \\
\hline 10 & $\begin{array}{l}\text { Model of the } \\
\text { initial human \& } \\
\text { financial capital } \\
\text { and venture } \\
\text { performance } \\
\text { prediction }\end{array}$ & $\begin{array}{l}\text { Cooper et al. } \\
\text { (1994) }\end{array}$ & $\begin{array}{l}\text { Initial } \\
\text { capital }\end{array}$ & $\begin{array}{l}\text { General } \\
\text { Human } \\
\text { capital, } \\
\text { Specific } \\
\text { Industry } \\
\text { Know-How, } \\
\text { Management } \\
\text { Know-How }\end{array}$ & & & \\
\hline 11 & $\begin{array}{l}\text { Model of } \\
\text { Entrepreneurial } \\
\text { Process (growth } \\
\text { phase of the } \\
\text { model) }\end{array}$ & Moore (1986) & $\begin{array}{l}\text { Starting } \\
\text { capital }\end{array}$ & $\begin{array}{l}\text { Education \& } \\
\text { Experience, } \\
\text { Managerial } \\
\text { ability }\end{array}$ & & & $\begin{array}{l}\text { Organizational } \\
\text { characteristics, } \\
\text { Environment }\end{array}$ \\
\hline
\end{tabular}


The above classifications of the various variables of entrepreneurial success confirm the discrepancy in the literature mentioned by Marom \& Lussier (2014) and justify the need to group the variables and benchmark it against the Expanding Capital Model of Entrepreneurial Success under its capitals; Financial, Human, Social and the Psychological capital.

\subsection{Entrepreneurial Success Indicators}

There are many variations in meanings of success to entrepreneurs, according to Angel, Jenkins, \& Stephens (2018) identified it as personal fulfillment, customer satisfaction, community impact, firm growth. While Wach et al. (2015) identified the most common criteria entrepreneurs use to define their success as firm performance, workplace relationships, personal fulfillment, community impact, and personal financial rewards. Wach et al. (2015) developed these criteria into a measuring scale of Entrepreneurial success named Subjective Entrepreneurial Success-Importance Scale (SES-IS). They tested (SES-IS) measuring scale for validity and reliability on three different samples; in 2008 on german entrepreneurs, in 2009 on polish entrepreneurs, and 2012 on another group of german entrepreneurs (Wach et al., 2018).

This study focused on the four factors: Financial capital, Human capital, Social capital, and Psychological capital and how they affect the entrepreneurial success in terms of firm performance, workplace relationships, personal fulfillment, community impact, and personal financial rewards.

\section{Theoretical Framework}

The expanding capital model of competitive advantage of Luthans et al (2004) was used and adapted by Envick (2005) to contribute in introducing the importance of psychological capital as well as the financial, human, and social capital when examining short-term and long-term entrepreneurial success (Envick, 2005)

The model reveals the importance of financial capital (what you have) in starting the venture along with the entrepreneur(s)' human capital (what you know), the social capital (who you know) that allows the venture to benefit from the entrepreneurs' network to gain more strength while highlighting the importance of the psychological capital (who you are) not only effectively mobilizing the entrepreneurs' financial, human, and social capital, but also in equipping the entrepreneur as explained by Hmieleski, Carr, \& Baron (2015) with "the mental, behavioral, and emotional resources that provide entrepreneurs with the capacity to respond effectively to challenging conditions to maintain focus and enthusiasm, and to both persevere after, and benefit from, major setbacks".

Accordingly, Figure 2 is a demonstration of the theoretical framework proposed in this research. The model has one dependent variable which is Entrepreneurial success and four independent variables; financial, human, social, and psychological capital.

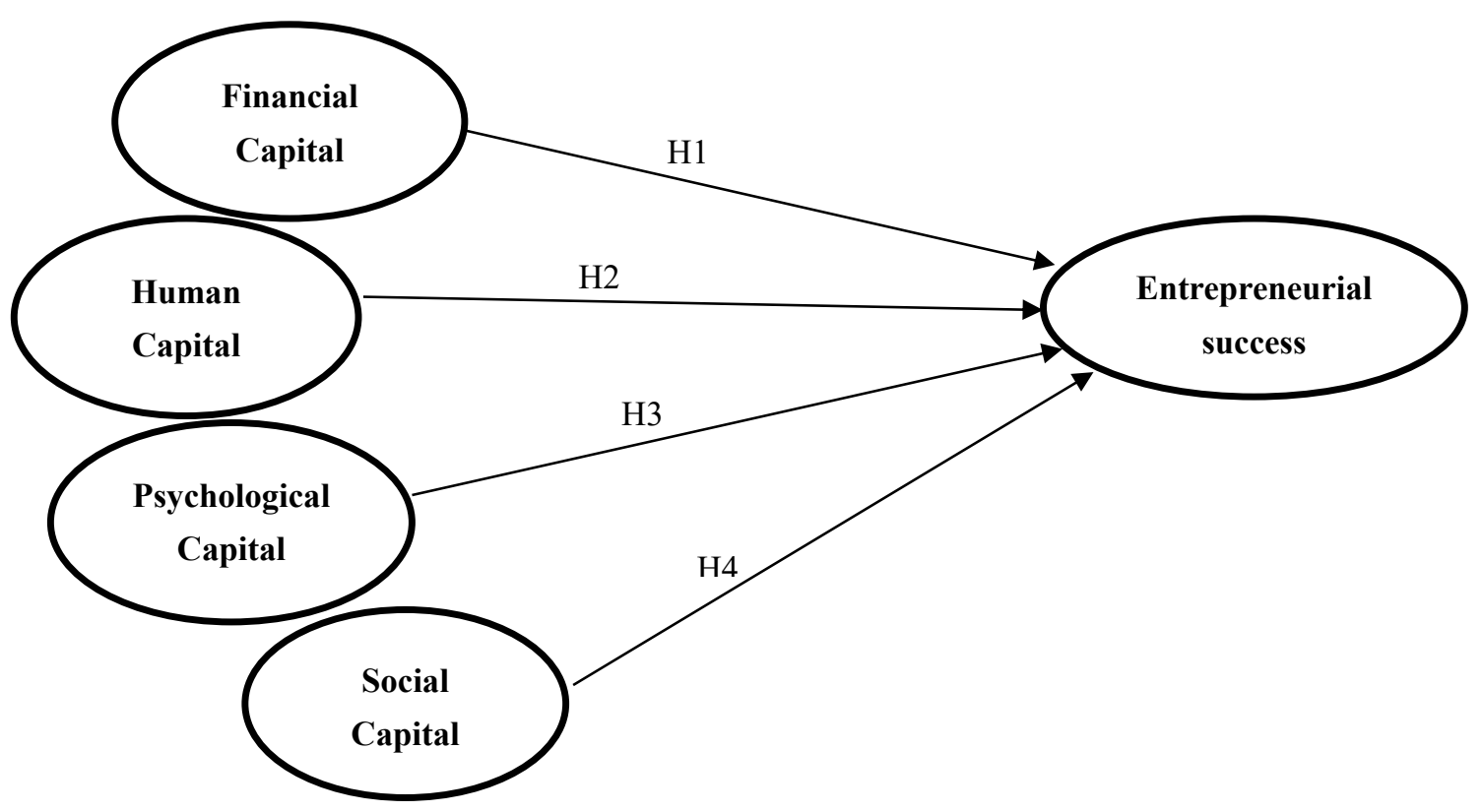

Figure 2. Theoretical Framework 


\subsection{Financial Capital and Entrepreneurial Success}

Financial capital consists of all the different types of monetary resources in which firms can use to create and enforce strategies (Ireland, Hitt, \& Sirmon, 2003). According to Ireland, Hitt, \& Sirmon (2003), financial capital can be used to acquire other resources, either tangible resources as equipment or intangible resources as human capital, it also provides the freedom to explore entrepreneurial opportunities. Financial capital is a "must-have" to start a venture along with other capitals such as Human capital (Envick, 2005), its amount contributes to the survival and growth of ventures (Cooper, Gimeno-Gascon , \& Woo, 1994). Other views amplify the fact that access to financial capital is important for the growth of the venture but not essentially for its creation (Kim, Aldrich, \& Keister, 2006).

The entrepreneur access to financial capital positively impacts the firm performance (Clarke, Seng, \& Whiting, 2011), as the growth of most small firms is controlled and restricted by the availability of internal finance (Petersen \& Carpenter, 2002), so external finance allows firms to grow and expand (Atieno, 2009), in specific the external debt finance (Fatoki, 2011).

Based on the above, the first hypothesis is that financial capital has an impact effect on entrepreneurial success.

(Ho1): Entrepreneurs' financial capital has no effect on entrepreneurial success in Egypt.

(Ha1): Entrepreneurs' financial capital affects entrepreneurial success positively in Egypt.

\subsection{Human Capital and Entrepreneurial Success}

According to Becker (1964), the human capital is defined as the knowledge and skills the individual acquires as an outcome of education and work experience (Unger, Rauch, Frese, \& Rosenbusch, 2011). There are two different concepts of human capital: the first, the human capital investment that includes education and work experience contrasted with the outcome of human capital investments which is knowledge and skills (Unger et al., 2011). The second concept is task-related human capital contrasted with human capital not-related to a specific task, by task-related it is meant that whether it addresses human capital investments and outcomes concerning a specific task or not, such as managing a business venture (Unger et al., 2011). Furthermore, there is the general human capital of entrepreneurs' (e.g., education and years of work experience) and specific human capital (e.g., industry-specific experience, business ownership experience, managerial, entrepreneurial, and technical capabilities), in which the specific variables were significantly related with a higher probability of identifying and pursuing more opportunities (Ucbasaran, Westhead, \& Wright, 2008). According to Ganotakis (2012), entrepreneurs with specific human capital, precisely with high levels of official business education, commercial, managerial, or same sector experience have formed ventures that are well-performing.

According to human capital theory, human capital leads to entrepreneurial success (Unger et al., 2011). Human capital increases the small firms' probabilities to survive (Brüderl, Preisendörfer, \& Ziegler, 1992). Human Capital in the form of strong background experience of founders allows businesses to survive and succeed with even less financial capital than their less experienced founders (Chandler \& Hanks, 1998). Human capital increases the capability of entrepreneurs to find and develop business opportunities (Shane \& Venkataraman, 2000), the existence of human capital tend to increase social capital to facilitate developing contacts (Dinda, 2008), it also affects social capital as experience and intellectual ability impact personal relations and involvement, thus influencing the organizational performance (Felício, Couto, \& Caiado, 2014), it allows entrepreneurs to leverage on their knowledge and experience to acquire financial and physical resources as well as hiring the qualified individual human resources (Brush, Greene, \& Hart, 2001). However, it is found that there is a strong but small relationship between human capital and success, the strength of the relationship is higher between knowledge/skills (outcomes of human capital investments) and success than for schooling years/work experience (human capital investments) and success, same for human capital that is high task-related compared to low task-related, for new businesses compared to established businesses (Unger et al., 2011).

Consequently, we hypothesize that the entrepreneur's human capital will have a positive effect on the entrepreneurial success and in particular, the generic human capital component: education \& work experience and the specific human capital components: entrepreneurial experience \& experience in the same industry.

(Ho2): Entrepreneurs' human capital has no effect on entrepreneurial success in Egypt.

(Ha2): Entrepreneurs' human capital affects entrepreneurial success positively in Egypt.

\subsection{Social Capital and Entrepreneurial Success}

Social capital is explained through the identification of networks and network relationships, sometimes defined by how strong the network ties are, or by the frequency of meetings and other formal interactions, as well as casual get-togethers and other social events and family relationships (Davidsson \& Honig, 2003). It is more appropriate to view social capital as a multidimensional approach rather than a one-dimensional, as it consists of three independent 
dimensions, structural, relational, and resources (Fornoni, Arribas, \& Vila, 2011).

Nahapiet \& Ghoshal (1998) identified three dimensions of social capital: structural, relational, and cognitive or resource. These three dimensions: the structural (social interaction ties), the relational (trust and trustworthiness), and the cognitive/resources (shared belief, goals, vision) were combined into a model of social capital and value creation which describes that the combination and exchange of information in a network create new sources of value, innovation or support for the entrepreneur (Ghoshal \& Tsai, 1998). While the structural dimension describes the pattern of linkages between two parties (Nahapiet \& Ghoshal, 1998), it focuses on who to connect to and how to connect to (Burt, 1992), relational dimension refers to the quality of these links (Vila, Fornoni, \& Palacios, 2013). And finally, the resource dimension implies the degree to which personal networks possess rich resources and powerful ties that when mobilized will produce high returns (Batjargal, 2003).

In view to social capital theory, a network provides many benefits to its members as it gives them access the social resources that are within the network, these benefits include access to information, access to financial or material resources as well as visibility and legitimacy within a social structure (Seibert, Kraimer, \& Liden, 2001). The high level of social capital help entrepreneurs to have access to key stakeholders such as potential customers or venture capitalists, with this initial access and depending on the nature of the interaction and the first impressions, the success of the networking is influenced (Baron \& Markman, 2000). The entrepreneur's social capital is positively associated with their familiarity of the finance alternatives at the start-up level (Seghers, Manigart, \& Vanacker, 2012). This availability of financial information leads to successful business decisions (Gibson, 1992). The social capital of the entrepreneur enables him/her to access to finance, thus it is encouraged for entrepreneurs to build relationships in his/her network (Boohene, 2018).

According to (Hormiga, Batista-Canino, \& Sánchez-Medina, 2011), establishing and developing a relationship with customers, friends, and acquaintances enables the entrepreneur to access key strategic information for the business. Thus, making it easier for businesses to be profitable (Davidsson \& Honig, 2003), but also the support that networks give, facilitates the growth and survival of new enterprises (Audretsch, 2003).

Consequently, we hypothesize that the entrepreneur's social capital will have a positive effect on entrepreneurial success.

(Ho3): Entrepreneurs' social capital has no effect on entrepreneurial success in Egypt.

(Ha3): Entrepreneurs' social capital affects entrepreneurial success positively in Egypt.

\subsection{Psychological Capital and Entrepreneurial Success}

For an entrepreneur to survive and thrive amid the economical, operational, and personal challenges, it requires more than traditional resources, human capital, and social capital. Entrepreneurs need to capitalize on their psychological capital (PsyCap) to be able to withstand business challenges and uncertainty (Luthan, Youssef, \& Avolio, 2007). It is obvious that financial, human, and social capital are still certainly essential, but they are no longer enough in this environment (Luthans, Avolio, Avey , \& Norman , 2007).

Psychological capital with its four states of confidence, optimism, resilience, and hope form the core of Self-efficacy or confidence is the power of believing you can (Maddux, 2002), as described by (Bandura, 2009) is the core belief that one has the power to produce the results they want, so unless people believe that they have this power, they have little motivation to act or persevere in the face of difficulty. Optimism refers to the expectation of people for the future, where optimistic people are the ones who expect a positive outcome even when things are hard (Carver \& Scheier, 2002). There are benefits to positive thinking, as expectancies influence how people confront situations and thus influencing the success with which people deal with them (Carver \& Scheier, 2002). While hope as defined by Snyder, et al. (1996) is "a cognitive set comprising agency (belief in one's capacity to initiate and sustain actions) and pathways (belief in one's capacity to generate routes) to reach goals", Envick (2005) described hope as a positive motivational state with two important components, the "willpower" and the "way power". In other words, hopeful thought reflects the belief that one can find pathways to desired goals and become driven to use those pathways (Snyder, Rand, \& Sigmon, 2002). Resilience is the process of adapting well in the face of adversity (Envick, 2005); it is the capacity to bounce back from hardship Luthans et al. (2004). The nature of the entrepreneurial ventures requires the entrepreneur to have the resilience to be able to bounce back from setbacks and adapt to given situations (Envick, 2005).

It is important to note that the four psychological capacities mentioned above (confidence, optimism, hope, and resilience) are all states rather than fixed traits, which means they all can be learned and developed in almost anyone Luthans et al. (2004). Also, they must be taken together as a package of personal strengths and valuable resources to succeed in entrepreneurial venturing (Juhdi, Abdul Hamid, Rizal, \& Juhdi, 2015), since psychological capital as a core construct is related to performance and satisfaction (Luthans, Avey, Avolio, Norman , \& Combs, 2006). 
The benefits of psychological capital are central to the success of entrepreneurs, it can be considered as the more vital, because entrepreneurs regularly face shortages of financial, human, and social capital, as a result, they often have only themselves to rely on in the face of the shortage of other resources in dynamic environments, under high levels of risk and uncertainty (Hmieleski \& Carr, 2008). Psychological capital is an important aspect of entrepreneurial success (Paul \& Dr. Devi, 2018), in which it provides entrepreneurs with the mental and emotional strengths needed to meet the emotional challenges that are part of the entrepreneurial process, therefore, psychological capital may be a critical reason in answering why some entrepreneurs can persevere and develop successful ventures with limited resources, while others do not (Hmieleski \& Carr, 2008).

Consequently, we hypothesize that the entrepreneur's psychological capital affects entrepreneurial success.

(Ho4): Entrepreneurs' psychological capital has no effect on entrepreneurial success in Egypt.

(Ha4): Entrepreneurs' psychological capital affects entrepreneurial success positively in Egypt.

According to Luthans, Youssef, \& Avolio (2007), to reach the individual's full potential, it is vital to integrate human, social, and psychological capital, whereas fundamental assets for the development of psychological capital are elements of human and social capital, this implies as Luthans, Youssef, \& Avolio (2007) argued that "PsyCap has a greater impact than human or social capital by themselves and that the whole (PsyCap) is greater than the sum of its parts [human and social capital]" (Luthan, Youssef, \& Avolio, 2007).

\section{Methodology}

\subsection{Design}

In this descriptive research, the researcher will use a deductive approach by implementing a quantitative methodology and correlation research design to analyze the significance of the factors that impact entrepreneurial success using a non-probability convenience sampling technique to withdraw one sample consisting of founders of ventures. Data of the research was collected at one time during December 2019; therefore, the study is a cross-sectional study.

\subsection{Population and Sample}

This study uses the non-probability sampling with a convenience sampling technique to collect the sample data. The research population consists of entrepreneurs with at least three years of business operations of either micro, small or medium enterprises: The research will target all entrepreneurs with at least three years of business operations in Egypt; the estimated population size is 200,000 Entrepreneur. The minimum size recommended by the sample calculator for the survey is 31 , with a 15 percent margin of error and a 90 percent confidence level.

The number of respondents that responded to the survey was 54, however, only 33 completed the survey which constitutes $(61.11 \%)$. Eleven respondents were excluded as they have less than three years of business operations. The majority of respondents lie between +34 to $44(45.5 \%)$ and +44 to 54 (30.3\%). Despite that youth respondents aged +24 to 34 are only (15.2\%) yet it reflects the obvious rise in the percentage of youth business owners as highlighted in GEM Egypt National Report 2017-2018 (Ismail et al., 2018). Among the total number of respondents, (78.8\%) of respondents were male entrepreneurs, and (21.2\%) were women entrepreneurs which are similar to the percentage provided by GEM Egypt National Report 2017-2018 (Ismail et al., 2018). Additionally, all respondents completed their higher education with (51.5\%) studied business and law.

\subsection{Instruments}

Entrepreneurial Success: five aspects of entrepreneurial Success were measured using a scale developed by Wach et al. (2018). Firm performance was measured by three items: Turnover / Sales, Profit Growth, Increased market share. Workplace relation was measured by five items: Employee satisfaction, Supportive firm culture, Social responsibility for employees, Strong employee relationships, Employee loyalty. Personal fulfillment was measured by three items: Personal work flexibility, Own decision-making, Personal development. Community impact was measured by three items: Firm's social contribution, Environmentally friendly, Social recognition. The personal financial rewards variable was measured by three items: Personal income growth, Personal financial security, Ability to afford a lot. Respondents indicated their agreement with each item on a six-point Likert scale (1 - not achieved at all to 6-absolutely achieved).

Financial Capital was measured by one item scale developed by Envick (2005), respondents indicated their agreement with each item on a six-point Likert scale ( 1 - strongly disagree, 3 - somewhat disagree, 4 - somewhat agree, and 6 strongly agree).

Human Capital was measured by six items scale adapted from Panić (2017). Respondents indicated their agreement with each item on a four-point Likert scale ( 1 - strongly disagree, and 4 - strongly agree).

Social Capital: Three aspects of social capital were measured using a scale developed by Fornoni et al. (2011). 
Structural was measured by seven items. The resources aspect was measured by four items. Relational was measured by four items. Respondents indicated their agreement with each item on a six-point Likert scale ( 1 - strongly disagree, 3 somewhat disagree, 4 - somewhat agree, and 6 - strongly agree).

Psychological Capital was measured by twelve items scale developed by Luthan, Avolio, \& Avey (2007). Respondents indicated their agreement with each item on a six-point Likert scale (1 - strongly disagree, 3 - somewhat disagree, 4 somewhat agree, and 6 - strongly agree).

\subsection{Data Analysis}

The sample data collected using an online survey was analyzed, the researchers applied quantitative data analysis using SPSS software for Reliability analysis using Cronbach's alpha, correlation analysis to measure the strength of the relationship between Entrepreneurial success and the four independent variables, simple linear regression test to measure to what extent there is a linear relationship between Entrepreneurial success and the four independent variances, and finally multiple regression using Stepwise Analysis to check the dependency between the Entrepreneurial success and the four independent variables and to test the model fit.

\section{Results}

\subsection{Constructs Validity \& Reliability Analysis}

The researcher used Cronbach's Alpha Analysis to test the internal consistency of items used to construct the variables of the proposed model. The test has shown that Social Capital, Psychological Capital, and Entrepreneurial Success had alpha values above (.70). However, the alpha value for Human Capital was found to be relatively lower, with a value of 0.50 which is moderately reliable (Hinton, Brownlow, McMurray, and Cozens, 2004).

\subsection{Normality Test}

The Shapiro-Wilk test of normality was used to test the normality of variables. This test was chosen above that of Kolmogorov-Smirnov because it was more appropriate for the small sample size less than 2000 (Razali \& Wah, 2011). Shapiro-Wilk test results for the variables Human Capital, Social Capital, Psychological Capital, and Entrepreneurial Success are not significant $(\mathrm{p}>0.05)$, indicating that the distribution of sample data of those variables is normal (Field, 2009). However, the Shapiro-Wilk test for the Financial capital variable is significant $(p=0.006)$. Therefore, the distribution of the sample is significantly different from a normal distribution. However, according to (Field, 2009) the normality test can be done using the z-scores of Skewness and Kurtosis, where the sample data can be considered normally distributed if these z-scores are less than \pm 1.96 . The z-score for the skewness and kurtosis for the variable "Financial capital" are (-0.98 and -0.86 respectively) which implies that the sample data of the Financial Capital can be considered normally distributed.

\subsection{Correlation Test}

Table 2 presents means and standard deviation and correlation coefficient among the model variables of the study.

Table 2. Correlation of the dependent variable (Entrepreneurial success) with the independent variables

\begin{tabular}{llllllll}
\hline & $\mathrm{M}$ & $\mathrm{SD}$ & 1 & 2 & 3 & 4 & 5 \\
\hline 1.Financial Capital & 3.55 & 1.44 & -- & & & & \\
2.Human Capital & 2.69 & 0.47 & .076 & -- & & & \\
3.Social Capital & 4.07 & 0.96 & $.394^{*}$ & -.002 & -- & & \\
4.Psychological capital & 4.86 & 0.55 & $.447^{* *}$ & .148 & $.497^{* *}$ & -- & \\
5.Entrepreneurial success & 4.37 & 0.58 & .115 & .234 & $.521^{* *}$ & $.558^{* *}$ & -- \\
\hline
\end{tabular}

*. Correlation is significant at the 0.05 level (1-tailed).

**. Correlation is significant at the 0.01 level (1-tailed).

According to the data in Table 2, the mean of Financial Capital is $(\mathrm{M}=3.55)$ where a 6-point Likert scale was used. This indicated the respondents' tendency toward agreeing on having access to finance to some extent. Additionally, the mean of Human Capital is $(\mathrm{M}=2.69)$, as a 4-point Likert scale was used. This indicated the tendency of respondents towards the importance of Human Capital. Also, the mean of Social Capital is $(\mathrm{M}=4.07)$, noting that a 6-point Likert scale was used; this showed the importance of social capital as per respondents. Moreover, the mean psychological capital is $(\mathrm{M}=4.86)$ where a 6-point Likert scale was used. This indicated that Psychological Capital is important in the context of this study. Finally, the mean of Entrepreneurial Success is $(\mathrm{M}=4.37)$ where a 6-point Likert scale was used indicated that most respondents exhibit Entrepreneurial success. 
Analyzing the correlation coefficients between the independent variables and the dependent variable showed that Social Capital has a statistically significant and strong positive relationship with Entrepreneurial success with a correlation coefficient $[\mathrm{r}=.521 . \mathrm{p}<.01]$. Also, Psychological Capital has a statistically significant and strong positive relationship with Entrepreneurial success with a correlation coefficient $[\mathrm{r}=.558, \mathrm{p}<.01]$ (Cohen, Cohen, West, \& Aiken, 2002). However, Human Capital has a statistically insignificant positive weak relationship with a correlation coefficient of $[\mathrm{r}=.234, \mathrm{p}=.095]$ with Entrepreneurial success. Finally, Financial Capital has a statistically insignificant positive weak relationship with a correlation coefficient of $[\mathrm{r}=.115, \mathrm{p}=.261]$ (Cohen, Cohen, West, \& Aiken, 2002).

\subsection{Simple Linear Regression Test}

Table 3. Regression Analysis between Financial Capital and Entrepreneurial Success

\begin{tabular}{llllll}
\hline Entrepreneurial success & $B$ & $S E B$ & $\beta$ & $t$ & $p$ \\
\hline Constant & 4.205 & .275 & & 15.264 & .000 \\
Financial Capital & .047 & .072 & .115 & .647 & .261 \\
\hline
\end{tabular}

$\mathrm{n}=33, \quad \mathrm{R}=.115, \quad \mathrm{R} 2=.013, \quad \mathrm{~F}=.419 \quad \mathrm{p}=.522$

Analyzing Table 3 shows Financial Capital cannot statistically and significantly predict Entrepreneurial Success $[F=.419, p=.522]$. Analyzing the standardized regression coefficient $[\beta=.115, p=.261]$ indicated that the level of Financial Capital is not a statistically significant predictor of Entrepreneurial Success. The results show that Financial capital with $[\mathrm{R}=.115, \mathrm{R} 2=.013]$ accounts for $1.3 \%$ of the total variance of Entrepreneurial Success. Therefore, the null hypothesis H1o cannot be rejected. Consequently, there is no relationship between Financial Capital and Entrepreneurial Success.

Table 4. Regression Analysis between Human Capital with Entrepreneurial Success

\begin{tabular}{llllll}
\hline Entrepreneurial success & $B$ & $S E B$ & $\beta$ & $t$ & $p$ \\
\hline Constant & 3.590 & .590 & & 6.082 & .000 \\
Human Capital & .291 & .158 & .234 & 1.343 & .095 \\
\hline
\end{tabular}

$\mathrm{n}=33, \quad \mathrm{R}=.234, \quad \mathrm{R} 2=.055, \quad \mathrm{~F}=1.803 \quad \mathrm{p}=.189$

Analyzing Table 4 shows Human Capital cannot statistically and significantly predict Entrepreneurial Success [F=1.803, $\mathrm{p}=.189]$. Analyzing the standardized regression coefficient $[\beta=.234, \mathrm{p}=.095]$ indicated that the level of Human Capital is not a statistically significant predictor of Entrepreneurial Success. The results show that Human capital with $[\mathrm{R}=.234, \mathrm{R} 2=.055]$ accounts for $5.5 \%$ of the total variance of Entrepreneurial Success. Therefore, the null hypothesis H2o cannot be rejected. Consequently, there is no relationship between Human Capital and Entrepreneurial Success.

Table 5. Regression Analysis between Social Capital with Entrepreneurial Success

\begin{tabular}{llllll}
\hline Entrepreneurial success & $B$ & $S E B$ & $\beta$ & $t$ & $p$ \\
\hline Constant & 3.084 & .389 & & 7.928 & .000 \\
Social Capital & .316 & .093 & .521 & 3.395 & .001 \\
\hline
\end{tabular}

$\mathrm{n}=33, \quad \mathrm{R}=.521, \quad \mathrm{R} 2=.271, \quad \mathrm{~F}=11.525 \quad \mathrm{p}<.01$

Analyzing Table 5 shows Social Capital statistically and significantly predicts Entrepreneurial Success [F=11.525, $\mathrm{p}<.01]$. Analyzing the standardized regression coefficient $[\beta=.521 . p<.01]$ indicated that the level of Social Capital is a statistically significant predictor of Entrepreneurial Success. The results show that Social capital with $[\mathrm{R}=.521$, $\mathrm{R} 2=.271$ ] accounts for $27.1 \%$ of the total variance of Entrepreneurial Success. Therefore, the null hypothesis H3o is rejected. Consequently, there is a positive linear relationship between Social Capital and Entrepreneurial Success.

Table 6. Regression Analysis between Psychological Capital with Entrepreneurial Success

\begin{tabular}{llllll}
\hline Entrepreneurial success & $B$ & $S E B$ & $\beta$ & $t$ & $p$ \\
\hline Constant & 1.495 & .773 & & 1.933 & .062 \\
Psychological capital & .591 & .158 & .558 & 3.742 & .000 \\
\hline
\end{tabular}

$\mathrm{n}=33, \quad \mathrm{R}=.558, \quad \mathrm{R} 2=.311, \quad \mathrm{~F}=14.004 \quad \mathrm{p}<.01$

Analyzing Table 6 shows Psychological Capital statistically and significantly predicts Entrepreneurial Success $[\mathrm{F}=14.004, \mathrm{p}<.01]$. Analyzing the standardized regression coefficient $[\beta=.558, \mathrm{p}<.01]$ indicated that Psychological Capital is a statistically significant predictor of Entrepreneurial Success. The results show that Psychological capital 
with $[\mathrm{R}=.558, \mathrm{R} 2=.311]$ accounts for $31.1 \%$ of the total variance of Entrepreneurial Success. Therefore, the null hypothesis $\mathrm{H} 4 \mathrm{o}$ is rejected. Consequently, there is a positive linear relationship between Psychological Capital and Entrepreneurial Success.

\subsection{Stepwise Multiple Regression Test}

The purpose of making the stepwise multiple regression is to test which of the statistically significant independent variables (Social Capital and the Psychological Capital) has the highest impact on Entrepreneurial success (Lewis-Beck, 1978; Huberty, 1989; Thompson, 1995). Accordingly, the Stepwise Multiple Regression displayed in Table 7, reveals that Psychological Capital has the highest effect suggested on Entrepreneurial success.

Table 7. Results of Stepwise Multiple Regression Test

\begin{tabular}{llllll}
\hline Entrepreneurial success & $B$ & $S E B$ & $\beta$ & $t$ & $p$ \\
\hline Constant & 1.495 & .773 & & 1.933 & .062 \\
Psychological capital & .591 & .158 & .558 & 3.742 & .000 \\
\hline $\mathrm{n}=33, \quad \mathrm{R}=.558, \quad \mathrm{R} 2=.311$, & $\mathrm{F}=14.004 \quad \mathrm{p}<.01$ & & & &
\end{tabular}

Analyzing Table 7 shows Psychological Capital statistically and significantly predicts Entrepreneurial Success $[\mathrm{F}=14.004, \mathrm{p}<.01]$. Analyzing the standardized regression coefficient $[\beta=.558, \mathrm{p}<.01]$ indicated that Psychological Capital is a statistically significant predictor of Entrepreneurial Success. The results show that Psychological capital with $[\mathrm{R}=.558, \mathrm{R} 2=.311]$ accounts for $31.1 \%$ of the total variance of Entrepreneurial Success.

Table 8. Excluded variable from Stepwise Multiple Regression Test

\begin{tabular}{llll}
\hline Entrepreneurial success & $\beta$ & $t$ & $p$ \\
\hline Financial Capital & -.167 & -1.004 & .323 \\
Human capital & .155 & 1.033 & .310 \\
Social capital & .323 & 1.965 & .059 \\
\hline
\end{tabular}

Analyzing Tables 7 and 8 shows that positive psychological capital is the independent variable that better predicts and explains the variance in the dependent variable Entrepreneurial success. This result supports that positive psychological capital is essential to start and sustain entrepreneurial ventures (Envick, 2005).

\section{Findings and Discussion}

The Expanding Capital for Entrepreneurial Success is the model adopted in this research. It implies the importance of having a financial capital to start the venture alongside with the entrepreneur(s)' human capital, social capital, and psychological capital to attain success (Envick, 2005), yet according to the regression analysis results, Financial Capital and Human Capital variables have an insignificant statistical impact on Entrepreneurial success as indicated in Tables 3 and 4.

The Expanding Capital for Entrepreneurial Success introduced the concept of positive psychological capital and argues that psychological capital is as important to all other forms of capital when examining short-term and long-term entrepreneurial success (Envick, 2005). The data analysis supports (Envick, 2005) suggestion, where Psychological Capital has a statistically significant impact on Entrepreneurial success as indicated in Table 6. Moreover, the Stepwise Multiple Regression displayed in Table 7, the Psychological Capital has the highest effect on Entrepreneurial success.

The Regression Analysis shows that Financial Capital was statistically insignificant to the dependent variable Entrepreneurial Success. This result suggests that start-ups and entrepreneurial ventures in Egypt can start with very little savings and succeed little by little over time, this is supported with the viewpoint that the access to financial capital is important for the growth of the venture but not essentially for its creation (Kim, Aldrich, \& Keister, 2006) and that the amount of the financial capital contributes to the survival and growth of ventures (Cooper, Gimeno-Gascon, \& Woo, 1994). Also, Regression Analysis shows that Human Capital was statistically insignificant to Entrepreneurial success. This result contradicts the literature where Unger et al., (2011) suggested that Human Capital has positive significance with success.

Additionally, the regression analysis showed that Social Capital has a statistically significant positive relationship with Entrepreneurial success. This result supports the literature that social capital is a vital intangible resource for a firm that by its existence allows new resources to be created rather than using existing ones (Chisholm \& Nielsen, 2009). Regarding the Psychological Capital, the regression analysis showed that it has a statistically significant positive relationship with Entrepreneurial success. This supports the literature that psychological capital is the latest intangible 
resource included (Keshvarz, Farahani, \& Saldehi, 2017) and is positively related to entrepreneurial success (Juhdi, Abdul Hamid, Rizal, \& Juhdi, 2015). The current study findings have also supported that positive psychological capital is essential to start and sustain entrepreneurial ventures (Envick, 2005) and that psychological capital is considered to be more vital than other capitals because entrepreneurs regularly face shortages of financial, human, and social capital so they often have only themselves to rely on in the face of the shortage of other resources (Hmieleski \& Carr, 2008).

The data analysis of stepwise multiple regression indicated in Table 8 showed that Psychological capital has the strongest positive relationship with Entrepreneurial success, which supports the study of Juhdi et al (2015) that emphasized that the Psychological states are valuable personal resources serious to small firm success and since psychological capital is a recognized state construct, our study suggests that it can be the most fundamental resource at the personal level (Juhdi, Abdul Hamid, Rizal, \& Juhdi, 2015).

\section{Conclusion}

This study aims to determine the impact of Financial Capital, Human Capital, Social Capital, and Psychological Capital on Entrepreneurial success in Egypt. The study contributes to the literature by suggesting the different capitals that affect entrepreneurial success in Egypt. This can help entrepreneurs to be aware of the skills and capabilities they need to focus on and develop to improve their likeliness to succeed. The study also provides insights to stakeholders such as investors, incubators, training companies, and accelerators on the profile of the entrepreneur that has the potential to thrive.

This study used the expanding capital model of (Luthans et al., 2004; Envick, 2005) for the proposed theoretical framework, which consisted of four independent variables; Financial Capital, Human Capital, Social Capital, and Psychological Capital and one dependent variable Entrepreneurial success. The data was collected through an online survey using non-probability sampling with a convenience sampling technique.

The statistical analysis showed that only two variables showed statistical significance to Entrepreneurial success. The two variables are Psychological capital and Social capital. However, the other two variables showed statistical insignificance to Entrepreneurial success; the Financial Capital and the Human Capital.

\section{Recommendations and Practical Implications}

This study concluded that the founders' capitals that impact Entrepreneurial Success are: Social Capital and Psychological capital. The study findings provide insights to entrepreneurs on the types of capital that impacts Entrepreneurial success and would be worth investing in. According to the analyzed results, the researchers suggest that Entrepreneurs should focus on developing Psychological capital as it has the highest impact on Entrepreneurial success. Psychological Capital with its four capacities (confidence, optimism, hope, and resilience) are all states rather than fixed traits that can be learned and developed and are vital to face the high risk and uncertain environment that Entrepreneur faces in Egypt.

For the Egyptian Entrepreneur to succeed in the existing environment, he/she needs more than financial, human, and social capital. The four states of psychological capital together are needed:

1- Confidence or Self-Efficacy is the core belief that one has the power to produce the results they want, as it gives the motivation to act or persevere in the face of difficulty (Bandura, 2009).

2- Optimism refers to the expectation in the positive outcome even when things are hard as it influences how people confront situations (Carver \& Scheier, 2002).

3- Hope is described by two important components, the "willpower" and the "way power", it reflects the belief that one can find pathways to desired goals and become driven to use those pathways (Snyder, Rand, \& Sigmon, 2002).

4- Resilience is the capacity to bounce back from hardship (Luthans et al., 2004) and adapt to given situations (Envick, 2005).

Additionally, this study provides some insights to training companies, incubators and any other entities that provide education and training to equip and support entrepreneurs to succeed, educating entrepreneurs on the importance of learning and developing psychological capital will prepare them to have confidence, optimism, hope and resilience to face challenges, persevere and come back stronger.

On the other hand, Social Capital as a statistical significant construct to Entrepreneurial Success reflects that social networks and the quality of its connections are not a luxury but rather worth to be invested in by entrepreneurs and it is recommended that entrepreneurs intentionally develop relationships with customers, friends, and acquaintances and focuses on who to connect to and how to connect to as well as to focus on the quality of these relationships. 


\section{Limitations and Future Research}

This research studied the effect of financial, human, social, and psychological capital of the entrepreneur on the entrepreneurial success in Egypt, the conclusion and results might not be relevant to other regions. Additionally, the sampling method is based on non-probability sampling with a convenience sampling technique, which may not be representing the whole population. Specifically, that most respondents belong to the upper-middle class and are highly educated. Future research can work on extending the sample to include various segments to allow for a broad view of results.

\section{References}

Angel, P., Jenkins, A., \& Stephens, A. (2018). Understanding Entrepreneurial Success: A Phenomenographic Approach. International Small Business Journal, 36(6), 611-36. https://doi.org/10.1177/0266242618768662

Atieno, R. (2009). Linkages, Access to Finance and the Performance of Small-Scale Enterprises in Kenya. Nairobi: Research paper / UNU-WIDER, No. 2009.06.

Audretsch, D. B. (2003). Entrepreneurship A survey of the literature.

Baidoun, S. D., Lussier, R. N., Burbar, M., \& Awashra, S. (2018). Prediction model of business success or failure for Palestinian small enterprises in the West Bank. Journal of Entrepreneurship in Emerging Economies, 60-80. https://doi.org/10.1108/JEEE-02-2017-0013

Bandura, A. (2009). Cultivate Self-efficacy for Personal and Organizational Effectiveness. In E. A. Locke. The Blackwell Handbook of Principles of Organizational Behavior, pp. 179-200. New York: Blackwell Publishing Ltd. https://doi.org/10.1002/9781119206422.ch10

Baron, R. A., \& Markman, G. D. (2000). Beyond social capital: How social skills can enhance entrepreneurs' success. Academy of Management Executive. https://doi.org/10.5465/ame.2000.2909843

Batjargal, B. (2003). Social Capital and Entrepreneurial Performance in Russia: A Longitudinal Study. sage journals. https://doi.org/10.1177/0170840603024004002

Becker, G. (1964). Human Capital, New York. Columbia University Press.

Boohene, R. (2018). Entrepreneur's Social Capital and Firm Growth: The Moderating Role of Access to Finance. Journal of Enterprising Culture, pp. 327-348. https://doi.org/10.1142/S0218495818500127

Brüderl, J., Preisendörfer, P., \& Ziegler, R. (1992). Survival Chances of Newly Founded Business Organization. American Sociological Review, pp. 227-242. https://doi.org/10.2307/2096207

Brush, C. G., Greene, P. G., \& Hart, M. M. (2001). From initial idea to unique advantage: The entrepreneurial challenge of constructing a resource base. Academy of Management Executive. https://doi.org/10.5465/ame.2001.4251394

Burt, R. S. (1992). The Social Structure of Competition. Cambridge, MA: Harvard University Press.

Bosma, N., Praag, M. v., Thurik, R., \& Wit, G. d. (2002, March). The Value of Human and Social Capital Investments for the Business Performance of Startups. SCALES (Scientific AnaLysis of Entrepreneurship and SMEs), pp. 1-11.

Carver, C. S., \& Scheier, M. F. (2002). Optimism. In C. Snyder, \& S. J. Lopez. Handbook of positive psychology, pp. 231-243. New York: Oxford University Press.

Chandler, G. N., \& Hanks, S. H. (1998). An examination of the substitutability of founders human and financial capital in emerging business ventures. Journal of Business Venturing, pp. 353-369. https://doi.org/10.1016/S0883-9026(97)00034-7

Chisholm, A. M., \& Nielsen, K. (2009). Social Capital and the Resource-Based View of the Firm. International Studies of Management \& Organization, pp. 7-32. https://doi.org/10.2753/IMO0020-8825390201

Clarke, M., Seng, D., \& Whiting, R. H. (2011). Intellectual Capital and Firm Performance in Australia. Journal of Intellectual Capital, pp. 505-530. https://doi.org/10.1108/14691931111181706

Cohen, J., Cohen, P., West, S. G., \& Aiken, L. S. (2002). Applied Multiple Regression/Correlation Analysis for the Behavioral Sciences (3rd ed.). Routledge; Third edition.

Cooper, A. C., Gimeno-Gascon, F. J., \& Woo, Y. C. (1994). Initial human and financial capital as predictors of new venture performance. Journal of Busines.s Venturing, pp. 371-395. https://doi.org/10.1016/0883-9026(94)90013-2

Davidsson, P., \& Honig, B. (2003). The role of social and human capital among nascent entrepreneurs. Journal of Business Venturing, pp. 301-331. https://doi.org/10.1016/S0883-9026(02)00097-6

Dinda, S. (2008). Social Capital in the creation of Human Capital and Economic Growth: A Productive Consumption Approach. Journal of Socio-Economics, pp. 2020-2033. https://doi.org/10.1016/j.socec.2007.06.014 
Erikoson, T. (2002). The Joint Influence of Interaction History and Time Horizon on VentureCapitalist/New-Venture Hide . Abstract College Entrepreneurship Research Conference (BCERC) Frontiers of Entrepreneurship Research 2007.

Elsafty, A. (2018). Lecture 2: Scientific Business Research Problem Definition [PowerPoint slides]. Retrieved from Maastricht School of Management, MBA Degree.

Elsafty, A. (2018). Lecture 2: Scientific Business Research Problem Definition [Lecture]. Retrieved from Maastricht School of Management, MBA Degree.

Elsafty, A. (2020, 1 21). DrAshrafElsafty Channel. Retrieved from Youtube: https://www.youtube.com/watch?v=y-jDT2iOOhU\&list=PLKSWZdnzp8p3uFLLh2N8_d0W7ZmJDLMjW\&index $=42 \& \mathrm{t}=628 \mathrm{~s}$

Elsafty, A., Elsayed, H., \& Shaaban, I. (2020). Journal of Education and Training Studies, 8(8), August 2020. ISSN 2324-805X E-ISSN 2324-8068. https://doi.org/10.11114/jets.v8i8.4901

Elsafty, A., Ragheb, M. (2020). Role of Human Resource Management towards Employees Retention during Covid-19 Pandemic. Business and Management Studies, 6(2), June 2020. ISSN: 2374-5916 E-ISSN: 2374-5924. https://doi.org/10.11114/bms.v6i2.4899

Elsafty, A., AlNawaly, A. (2020). Role of Co-Working Spaces' Services in Entrepreneurs Growth in Upper Egypt, The Case of Step Co-Working Space. Business and Management Studies, 6(2), June 2020. ISSN: 2374-5916 E-ISSN: 2374-5924. https://doi.org/10.11114/bms.v6i2.4898

Elsafty, A., Elsayed, H., \& Shaaban, I. (2020), A Business Analysis Perspective for Engineering Education in Egypt. Journal of Education and Training Studies, 8(5), May 2020. ISSN 2324-805X E-ISSN 2324-8068. https://doi.org/10.11114/jets.v8i5.4721

Elsafty, A., Elsayed, H., \& Shaaban, I. (2020). Educating Engineering Students in Egypt: Recommendations for Improvement. International Journal of Higher Education. https://doi.org/10.5430/ijhe.v9n3p1

Envick, R. B. (2005). Beyond Human And Social Capital: The Importance Of Positive Psychological Capital For Entrepreneurial Success. Academy of Entrepreneurship, pp. 41-52.

Fatoki, O. O. (2011). The Impact of Human, Social and Financial Capital on the Performance of Small and Medium-Sized Enterprises (SMEs) in South Africa. Journal of Social Sciences, pp. 193-204. https://doi.org/10.1080/09718923.2011.11892970

Felício, J. A., Couto, E., \& Caiado, J. (2014). Human capital, social capital and organizational performance. Management Decision, pp. 350-364. https://doi.org/10.1108/MD-04-2013-0260

Field, A. (2009) Discovering Statistics Using SPSS. (3rd ed.), Sage Publications Ltd., London.

Fisher, R., Maritz, A., \& Lobo, A. (2014). Evaluating entrepreneurs' perception of success: Development of a measure scale. European Journal of Marketing. https://doi.org/10.1108/IJEBR-10-2013-0157

Fornoni, M., Arribas, I., \& Vila, J. E. (2011). Measurement of an individual entrepreneur's social capital: a multidimensional model. International Entrepreneurship and Management Journal, pp. 495-507. https://doi.org/10.1007/s11365-011-0204-1

Ganotakis, P. (2012). Founders' human capital and the performance of UK new technology based firms. Small Business Economics, pp. 495-515. https://doi.org/10.1007/s11187-010-9309-0

Ghoshal, S., \& Tsai, W. (1998). Social Capital and Value Creation The Role of Intrafirm Networks. The Academy of Management Journal, pp. 464-476. https://doi.org/10.2307/257085

Gibson, B. (1992). Financial Information for Decision Making: An Alternative Small Firm Perspective. JOURNAL OF SMALL BUSINESS FINANCE, pp. 221-232.

Gorgievski, M., Ascalon, M. E., \& Stephan, U. (2011). Small Business Owners' Success Criteria, a Values Approach to Personal Differences. Journal of Small Business Management, pp. 207-232. https://doi.org/10.1111/j.1540-627X.2011.00322.x

Hinton, P. R., Brownlow, C., McMurray, I. \& Cozens, B. (2011) SPSS Explained. Introduction to Factor Analysis. Routledge Taylor \& Francis Group, London, pp. 339-354.

Hmieleski, K. M., \& Carr, J. C. (2008). The Relationship Between Entrepreneur Psychological Capital And New Venture Performance. Frontiers of Entrepreneurship Research.

Hmieleski, K. M., Carr, J. C., \& Baron, R. A. (2015). Integrating Discovery And Creation Perspectives Of Entrepreneurial Action: The Relative Roles Of Founding Ceo Human Capital, Social Capital, And Psychological 
Capital In Contexts Of Risk Versus Uncertainty. Strategic Entrepreneurship Journal, pp. 289-312. https://doi.org/10.1002/sej.1208

Hormiga, E., Batista-Canino, R. M., \& Sánchez-Medina, A. (2011). The Impact of Relational Capital on the Success of New Business Start-Ups. Journal of Small Business Management, pp. 617-638. https://doi.org/10.1111/j.1540-627X.2011.00339.x

Huberty, C. J (1989). Problems with stepwise methods-better alternatives. In B. Thompson (Ed.), Advances in social science methodology, 1, 43-70. Greenwich, CT: JAI Press.

Ireland, R. D., Hitt, M. A., \& Sirmon, D. G. (2003). A Model of Strategic Entrepreneurship: The Construct and its Dimensions. Journal of Management, pp. 963-989. https://doi.org/10.1016/S0149-2063(03)00086-2

Ismail, A., Tolba, A., Barakat, S., \& Meshreki, H. (2018). Global Entrepreneurship Monitor. Egypt National Report 2017-2018. Cairo.

Juhdi, H. N., Abdul Hamid, R., Rizal, A. M., \& Juhdi, N. (2015). Psychological Capital and Entrepreneurial Success: a Multiple-Mediated Relationship. European Journal of Interdisciplinary Studies. https://doi.org/10.26417/ejis.v1i2.p110-133

Keshvarz, L., Farahani, A., \& Saldehi, M. (2017). Organizational Intangible Assets (human, social and psychological capitals) and Corporate Entrepreneurship - Case Study: Ministry of Sport and Youth of Islamic Republic of Iran. International Journal of Pharmaceutical Research \& Allied Sciences, pp. 79-92.

Kim, P. H., Aldrich, E. H., \& Keister, L. A. (2006). The Impact of Financial, Human, and Cultural Capital on Entrepreneurial Entry in the United States. Small Business Economics, pp. 5-22. https://doi.org/10.1007/s11187-006-0007-x

Kumar, M. (2007). Explaining Enterpreneurial Success: a conceptual model. Academy of Enterpreneurship Journal.

Lewis-Beck, M. (1978). Stepwise Regression: A Caution. Political Methodology, 5(2), 213-240. Retrieved August 6, 2020, from www.jstor.org/stable/25791533

Lussier, R. N. (1995). A nonfinancial business success versus failure prediction model for young firms. Journal of Small Business Management.

Luthan, F., Youssef, C. M., \& Avolio, B. J. (2007). Psychological Capital: Developing the Human Competitive Edge. New York: OXFORD UNIVERSITY PRESS.

Luthans, F., Avolio, B. J., Avey, J. B., \& Norman, S. M. (2007). Positive psychological capital: measurement and relationship with performance and satisfaction. Personnel Psychology, pp. 541-572. https://doi.org/10.1111/j.1744-6570.2007.00083.x

Luthans, F., Avey, J. B., Avolio, B. J., Norman, S. M., \& Combs, G. M. (2006). Psychological capital development: toward a micro-intervention. Journal of Organizational Behaviour, pp. 387-393. https://doi.org/10.1002/job.373

Luthans, F., Luthans, K. W., \& Luthans, B. C. (2004). Positive psychological capital: Beyond human and social capital. Business Horizons, pp. 45-50. https://doi.org/10.1016/j.bushor.2003.11.007

Maddux, J. E. (2002). Self-Efficacy The power of believing you can. In C. Snyder, \& S. Lopez. Handbook of Positive Psychology, pp. 277-287. New York: Oxford University Press.

Makhbul, Z. M., \& Hasun, F. M. (2011). Entrepreneurial Success: An Exploratory Study among Entrepreneurs. International Journal of Business and Management. https://doi.org/10.5539/ijbm.v6n1p116

Marom, S., \& Lussier, R. N. (2014). A Business Success Versus Failure Prediction Model for Small Businesses in Israel. Business and Economic Research. https://doi.org/10.5296/ber.v4i2.5997

Miner, J. B. (1997). A psychological typology of successful entrepreneurs. Quorum Books/Greenwood Publishing Group.

Moore, C. F. (1986). Understanding entrepreneurial behavior. In J.A. Pearce\& R.B. Robinson, editors, Academy of Management best papers, Forty-Sixth Annual Meeting, Academy of management,Chicago. https://doi.org/10.5465/ambpp.1986.4978712

Nahapiet, J., \& Ghoshal, S. (1998). Social Capital, Intellectual Capital, And The Organizational Advantage. Academy of Management Review, pp. 242-266. https://doi.org/10.5465/amr.1998.533225

Orser, B., \& Dyke, L. (2009) The influence of gender and occupational-role on entrepreneurs' and corporate managers' success criteria. Journal of Small Business and Entrepreneurship, 22(3), 327-353. https://doi.org/10.1080/08276331.2009.10593459 
Paul, M. T., \& Dr. Devi, N. U. (2018). Exploring the relationship between psychological capital and entrepreneurial success. International Journal of Pure and Applied Mathematics, pp. 2987-2999.

Petersen, B., \& Carpenter, R. (2002). Is The Growth Of Small Firms Constrained By Internal Finance? Review of Economics and Statistics, pp. 298-309. https://doi.org/10.1162/003465302317411541

Rauch, A., \& Frese, M. (2000). Psychological approaches to entrepreneurial success: A general model and an overview of findings. (C. Cooper, \& I. Robertson, Eds.) International Review of Industrial and Organisational Psychology, $10,1-41$.

Razali, N., \& Wah, Y. (2011). Power Comparisons of Shapiro-Wilk, Kolmogorov-Smirnov, Lilliefors and Anderson-Darling Tests. Journal of Statistical Modeling and Analytics, pp. 21-33.

Seghers, A., Manigart, S., \& Vanacker, T. (2012). The Impact of Human and Social Capital on Entrepreneurs' Knowledge of Finance Alternatives. Journal of Small Business Management, pp. 63-86. https://doi.org/10.1111/j.1540-627X.2011.00344.X

Seibert, S. E., Kraimer, M. L., \& Liden, R. C. (2001). A Social Capital Theory Of Career Success. Academy of Management Journal, pp. 219-237. https://doi.org/10.2307/3069452

Shane, S., \& Venkataraman, S. (2000). The Promise Of Entrepreneurship As A Field Of Research. Academy of Management Review, pp. 217-226. https://doi.org/10.5465/amr.2000.2791611

Snyder, C., Rand, K. L., \& Sigmon, D. R. (2002). Hope Theory. In C. Snyder, \& S. Lopez, Handbook of Positive Psychology, pp. 257-276. New York: Oxford University Press.

Snyder, C., Sympson, S. C., Ybasco, F. C., Borders, T. F., Babyak, M. A., \& Higgins, R. L. (1996). Development and validation of the State Hope Scale. Journal of Personality \& Social Psychology, pp. 321-335. https://doi.org/10.1037/0022-3514.70.2.321

Taormina, R., \& Lao, S.-M. (2007). Measuring Chinese entrepreneurial motivation: Personality and environmental influences. International Journal of Entrepreneurial Behaviour \& Research, pp. 200-221. https://doi.org/10.1108/13552550710759997

Thompson, B. (1995). Stepwise regression and stepwise discriminant analysis need not apply here: A guidelines editorial. Educational and Psychological Measurement, 55, pp. 525-534. https://doi.org/10.1177/0013164495055004001

Ucbasaran, D., Westhead, P., \& Wright, M. (2008). Opportunity Identification and Pursuit: Does an Entrepreneur's Human Capital Matter? Small Business Economics, pp. 153-173. https://doi.org/10.1007/s11187-006-9020-3

Unger, J., Rauch, A., Frese, M., \& Rosenbusch, N. (2011). Human capital and entrepreneurial success: A metaanalytical review. Journal of Business Venturing, pp. 341-358. https://doi.org/10.1016/j.jbusvent.2009.09.004

Vesper, K. H. (1990). New Venture Strategies. 2nd Edition. N.J. : Prentice Hall: Englewood Cliffs.

Vila, J. E., Fornoni, M., \& Palacios, D. (2013). Multidimensional social capital in new ventures. The Service Industries Journal, pp. 820-832. https://doi.org/10.1080/02642069.2013.719892

Wach, D., Stephan, U., \& Gorgievski, M. (2015). More than money: Developing an integrative multi-factorial measure of entrepreneurial success. International Small Business Journal, pp. 1098-1121. https://doi.org/10.1177/0266242615608469

Wach, D., Stephan, U., Gorgievski, M., \& Wegge, J. (2018). Entrepreneurs' Subjective Assessment of Success: Development of a Multifaceted Measure. International Entrepreneurship and Management Journal. https://doi.org/10.5465/AMBPP.2017.15063abstract

Watson, K., Hogarth-Scott, S., \& Wilson, N. ( 1998). Small business start-ups: success factors and support implications. International Journal of Entrepreneurial Behaviour, pp. 217-238. https://doi.org/10.1108/13552559810235510

\section{Copyrights}

Copyright for this article is retained by the author(s), with first publication rights granted to the journal.

This is an open-access article distributed under the terms and conditions of the Creative Commons Attribution license which permits unrestricted use, distribution, and reproduction in any medium, provided the original work is properly cited. 